\title{
KCNMA1 wt Allele
}

National Cancer Institute

\section{Source}

National Cancer Institute. KCNMA1 wt Allele. NCI Thesaurus. Code C101364.

Human KCNMA1 wild-type allele is located in the vicinity of $10 \mathrm{q} 22.3$ and is approximately $769 \mathrm{~kb}$ in length. This allele, which encodes calcium-activated potassium channel subunit alpha-1 protein, is involved in the regulation of potassium transport. Aberrant expression of the gene may play a role in melanoma. 